\title{
Sławomir Kadrow*
}

Instytut Archeologii i Etnologii PAN

\section{Dariusz Wojakowski**}

AGH Akademia Górniczo-Hutnicza

\section{O DYSKURSIE ARCHEOLOGICZNO-SOCJOLOGICZNYM}

\begin{abstract}
Artykuł jest próbą przedstawienia zasadniczych problemów teoretycznych i poznawczych, które wydają się wspólne dla archeologii i socjologii. Istnienie łączących te dyscypliny zagadnień umożliwia nie tylko prowadzenie wspólnego dyskursu naukowego, ale też może inspirować rozwój każdej z tych dyscyplin. W naszym przekonaniu szczególnie inspirująca poznawczo jest wspólna refleksja nad znaczeniem „rzeczy” dla istnienia społecznego świata, w tym rozpoznania mechanizmów tworzenia życia codziennego. Ponadto obydwie dyscypliny mają podobne doświadczenia z wielością paradygmatów teoretyczno-metodologicznych, zmagają się też - stosując bardzo odmienne perspektywy czasowe - z problemem zmiany i trwania kultury.
\end{abstract}

Słowa kluczowe: dyskurs archeologiczno-socjologiczny, ,powrót do rzeczy” w humanistyce, teorie społeczeństwa a badania archeologiczne, archeologia a socjologia życia codziennego

Od 2008 roku autorzy tego tekstu prowadzą ogólnopolskie seminarium interdyscyplinarne „Przestrzeń - Władza - Religia”, które gościło przez pięć rocznych edycji przede wszystkim archeologów, socjologów i historyków, ale też zainteresowanych tematyką seminarium etnografów, filozofów i politologów. Owocem pierwszych trzech edycji były prace zawarte w 6. tomie czasopisma Analecta Archeologica Resoviensia (2011). Niniejszy zeszyt jest zbiorem artykułów, które powstały w wyniku spotkań seminaryjnych czwartej edycji seminarium (2012/2013). Współpraca z socjologami i archeologami zadającymi sobie podobne pytania badawcze i jednocześnie reprezentującymi wewnątrz swoich dyscyplin różne tradycje teoretyczne czy stanowiska metodologiczne przekonuje nas o istnieniu znaczącej wartości dodanej w dyskursie archeologiczno-socjologicznym. Mamy nadzieję, że można to zauważyć w zawartych w zeszycie opracowaniach. Niniejszy artykuł jest też próbą wyrażenia tego przekonania z zachowaniem dwóch perspektyw spojrzenia na relacje socjologii i archeologii. Wieloletnia współpraca właściwie utrudnia określenie, na ile wątki, które poruszamy, prowadzone są

* Adres do korespondencji: Sławomir Kadrow, Instytut Archeologii i Etnologii PAN, ul. Sławkowska 17, 31-016 Kraków; e-mail: slawekkadrow@gmail.com.

** Adres do korespondencji: Dariusz Wojakowski, Wydział Humanistyczny AGH, ul. Gramatyka 8a, 30-071 Kraków; e-mail: wojakd@agh.edu.pl. 
niezależnie lub wspólnie - to należy oceniać w kontekście całości prac znajdujących się w tym zeszycie. Interesują nas te same zagadnienia, gdyż socjologię i archeologię nurtują dziś podobne problemy teoretyczne i poznawcze. Czasem patrzymy na nie $\mathbf{z}$ innej perspektywy, choć trzeba się zgodzić, że kierunki refleksji teoretycznej w obu dyscyplinach - choć różnorodne - są bardzo sobie bliskie. W związku z tym zapewne dochodzimy do podobnych wniosków, które przedstawiamy na końcu artykułu.

\section{CZEGO ARCHEOLOG OCZEKUJE OD SOCJOLOGII? ${ }^{1}$}

W twórczości naukowej wszechstronnego humanisty z czasów oświecenia - Johanna Joachima Winckelmanna (1717-1768), ojca archeologii klasycznej i twórcy metody typologicznej w historii sztuki i w archeologii, autora wielotomowej Geschichte der Kunst des Alterthums, antycypowana jest jedna z niezwykle ważnych teorii dla rozwoju nauk społecznych i historycznych $\mathrm{w}$ dwu następnych stuleciach. U podstaw sformułowanej przez J. Winkelmanna typologii antycznej rzeźby greckiej leży przekonanie o tym, że sztuka jako część kultury zmienia się w czasie na podobieństwo żywego organizmu. Porządkując znane już w XVIII wieku zabytki rzeźby greckiej, wyróżnił trzy etapy chronologiczne. Do etapu najstarszego zaliczył rzeźby z okresu archaicznego, do etapu średniego - rzeźby klasyczne, a do etapu najmłodszego - zabytki z okresu hellenistycznego. Te pierwsze porównał do dzieciństwa, drugie do okresu dojrzałości, a ostatnie do starości w życiu każdego żywego osobnika (Schnapp i Kristiansen 1999). Był więc prekursorem naukowo zdefiniowanej dopiero w połowie XIX wieku koncepcji kultury, integralnej części życia społecznego, której metaforą są koleje życia przedstawicieli świata organicznego (por. np. Kadrow 2009, 269-273).

W momencie narodzin nowożytnej socjologii utrwaliło się rozróżnienie na "statykę" i „dynamikę" społeczną w terminologii Augusta Comte'a oraz na „strukturę" i funkcję” w ujęciu Herberta Spencera (por. Turner 2004, 9-10). U jego podstaw legła analogia między społeczeństwem i jego kulturą a jednostkowym organizmem biologicznym. Statyka społeczna (struktura) była pojmowana jako nauka o anatomii społeczeństwa, analogicznie np. do anatomii ciała ludzkiego. Dynamika społeczna (funkcja) zajmowała się natomiast procesami wewnątrz społeczeństwa na podobieństwo fizjologii organizmu. Rdzeń takiego pojmowania społeczeństwa i jego kultury powtarza się w funkcjonalizmie, a także w teorii systemów (Sztompka 2005, 20).

Drugim filarem rozwoju nauk społecznych i historycznych w XIX i XX wieku, w tym również archeologii, była teoria ewolucji społecznej (Morgan 1877). Powstała ona już w czasach oświecenia (Pare 2008). U jej podstaw leży przekonanie o postępowych, wzajemnie powiązanych $i$ warunkowanych zmianach społecznych $i$ technologicznych cywilizacji ludzkiej. Dzieje ludzkości toczyły się w ramach trzech etapów: dzikości, barbarzyństwa i cywilizacji (por. Szacki 2007, 307-310; Kadrow 2011a, 41; Tabaczyński 2012, 735).

Oba przywołane wyżej filary teorii nauk społecznych i historycznych przeniknęły, często za pośrednictwem antropologii kulturowej, do archeologii i konstytuują do dzisiaj jej najważniejsze szkoły i kierunki.

Autorem tej części rozdziału jest Sławomir Kadrow. 
Przełom w archeologii, polegający na zastąpieniu scjentystycznie zorientowanej nowej archeologii archeologią kontekstualną i archeologią postprocesualną, sporo zawdzięcza bezpośrednim inspiracjom płynącym z socjologii (Hodder 1995, 96-102). Były to przede wszystkim teoria praktyki (Bourdieu 2007) i teoria strukturacji (Giddens 2003). Zharmonizowanie tych teorii m.in. z metodą historyczną Robina G. Collingwooda i hermeneutyczną filozofią poznania Hansa-Georga Gadamera pozwoliło ponownie przestawić archeologię na tory humanistyki (Hodder 1995, 218-230).

Społeczeństwo i jego kultura przestały być postrzegane jedynie jako metafory organizmu czy też systemy. W próbach rekonstrukcji społeczno-kulturowego procesu dziejowego zaczęto szukać bardziej adekwatnych modeli socjologicznych. Bardziej humanistycznie zorientowani archeolodzy, dla których daleko niewystarczające są modele archeologii kulturowo-historycznej, szukają inspiracji szczególnie w tych kierunkach socjologii, dla których ważny jest diachroniczny wymiar procesów społecznych. Za przykład niech posłużą prace (np. Johansen, Laursen i Holst 2004) wykorzystujące koncepcję stawania się społeczeństwa Piotra Sztompki (1991). Innym przykładem są prace (np. Kadrow 2011b), których autorzy korzystają z teorii ewolucji kulturowej Jürgena Habermasa (1983) lub też dzieła (np. Dzbyński 2008) inspirowane teorią działania komunikacyjnego wspomnianego wcześniej socjologa (Habermas 1999; Habermas 2002). Warto też wspomnieć o inspiracjach socjologią Maxa Webera w rekonstrukcjach procesów kształtowania się różnych form władzy i panowania w pradziejach (np. Rossignol i Wehner 2010).

Nowym wyzwaniem dla archeologii (np. Domańska i Olsen 2008; Urbańczyk 2006) jest twórcza adaptacja interdyscyplinarnego prądu intelektualnego, obecnego również w socjologii (np. Dant 2007; Krajewski 2008) i w innych dyscyplinach naukowych (np. Barański 2007), którego zwolennicy skupiają się na analizach kultury materialnej, znanego pod ogólną nazwą „powrotu do rzeczy”. Kultura materialna, rzeczy, zabytki to podstawowe źródła do poznania przeszłości, którymi dysponuje archeologia, zmuszona niejako z tego powodu do rozwinięcia i pogłębienia wielokierunkowych i wielopłaszczyznowych studiów nad rzeczami, przedmiotami (zabytkami). Są to różnego typu efektywne poznawczo klasyfikacje rzeczy (elementów kultury materialnej) zmierzające do ustalenia zmiennych reguł łączenia się formy i stylu danego artefaktu z jego usytuowaniem w czasie i przestrzeni kulturowej oraz społecznej w jej najróżniejszych wymiarach (społecznym, etnicznym, pokoleniowym, zawodowym, warstwowym, genderowym itd.).

Archeologia oczekuje, że socjologia i inne nauki społeczne podejmą trud pogłębienia swych interesujących studiów nad kulturą materialną, przeanalizują związki badanych, rozgrywających się współcześnie procesów i zjawisk społeczno-kulturowych z formą i stylem zaangażowanych w te procesy rzeczy. Analiza artefaktów dostarczyć może istotnych informacji o ludziach posługujących się nimi. Wiedza ta jest znacznie większa niż ta wynikająca z badań ankietowych. Jest to tym ważniejsze, że w środowisku socjologów i antropologów kulturowych narasta świadomość tego, że obywanie się bez rzeczy i poprzestawanie w studiach na przekonaniach, wartościach, wierzeniach i obyczajach może prowadzić do błędnych wniosków (np. Barański 2007, 28; Dant 2007, 209-214).

W tego typu próbach zmierzających do poszerzenia studiów socjologicznych nad rzeczami niezbędna wydaje się współpraca $\mathrm{z}$ archeologami. Już ponad sto pięćdziesiąt 
lat temu o funkcjach i znaczeniach rzeczy archeolodzy sądzili na podstawie tzw. analogii etnograficznych (np. Podgorny 2000). W późniejszym okresie ważną rolę odegrały studia etnoarcheologiczne (np. Van Reybrouck 2000), jeszcze później kontekstualne (Hodder 1995). Zaawansowane są też studia nad związkami idei, umysłu i materialności (por. np. DeMarrais, Gosden i Renfrew 2004).

Nowe nadzieje dla archeologii stwarzają także socjologiczne teorie społeczeństwa sieci (np. Barney 2008; Castells 2013). W koncepcji Michela Maffesoli we współczesnych społeczeństwach sieci zaskakuje obecność pewnych archaicznych cech, takich jak m.in.: wspólnotowość, uspołecznienie, schodzenie na dalszy plan racjonalizmu, przewaga aury estetyki nad doświadczeniem etycznym, które pozwalają nadać im miano społeczeństw trybalnych, „nowoplemiennych” (Maffesoli 2008, 31-40). Odkrycie strukturalnych paraleli między społeczeństwami ponowoczesnymi a trybalnymi skłania archeologów do skorzystania z bogatego zestawu metod analitycznych do badań społeczeństwa sieci (np. badania przestrzeni przepływów; por. Castells 2013, 405-452) w studiach nad społecznościami pradziejowymi (np. Furholt 2009).

Jednakże i w tym przypadku archeologia oczekuje od socjologii głębszego zainteresowania się kulturą materialną, formą i stylem rzeczy . Umożliwi to bardziej adekwatne korzystanie przez archeologów z doświadczeń nauk społecznych w ich studiach nad pradziejową przeszłością, czyli nad czasami, w przypadku których zbadanie rzeczy to jedyne dostępne źródło informacji.

Archeologia oferuje socjologii i innym naukom społecznym oraz humanistycznym niezwykłą głębię obserwacji procesów społecznych i kulturowych w czasie, liczoną w wiekach i w tysiącleciach, nieporównywalną z perspektywami czasowymi żadnej innej nauki. Pewne procesy dziejowe, takie jak na przykład etnogeneza (Gumilow 1997) czy też pochodzenie instytucji politycznych (por. Fukuyama 2012) oraz wiele innych, dają się zaobserwować tylko w perspektywie długiego trwania. Archeologia oferuje ponadto zestaw procedur analitycznych i rozległe doświadczenia w klasyfikacyjnych studiach nad formami i stylem rzeczy, składników kultury materialnej. W studiach tego typu leży ogromny potencjał poznawczy - o czym wspomniano już wyżej - wykorzystywany z reguły przez inne nauki społeczne i humanistyczne.

\section{PO CO SOCJOLOGII ARCHEOLOGIA?²}

Socjologia i inni. Pytanie o przydatność innych dyscyplin naukowych dla refleksji socjologicznej łączy się ze złożoną historią relacji interdyscyplinarnych. W środowisku socjologicznym - wydaje się - istnieją pewne dość silnie zakorzenione stereotypy postrzegania własnej relacji z innymi dyscyplinami humanistycznymi (czy też społecznymi), które trwają niezależnie od przemian paradygmatycznych czy form uprawiania socjologii. Ich źródło wiąże się z początkami tej dyscypliny. Implicite tkwi w myśleniu socjologicznym specyficzna interpretacja Comte'owskiej idei socjologii jako zwieńczenia nauk. W obszarze nauk humanistycznych, w których zamiast metodologii mamy metateoretyzowanie, a zamiast paradygmatów

\footnotetext{
2 Autorem tej części artykułu jest Dariusz Wojakowski.
} 
perspektywy teoretyczne (por. Sojak 2004: 67), socjologia mimo swych zapóźnień wobec nauk ścisłych jest ostoją metody, języka i paradygmatyczności. Na tej podstawie pewne fakty tych nauk można interpretować tak, że oto inne, spokrewnione dyscypliny naśladują socjologiczne rozwiązania, chcąc osiągnąć poziom naukowości do socjologii zbliżony. Socjolodzy uważają też, że przedstawiciele owych pokrewnych dyscyplin przenoszą się do samej socjologii i próbują być socjologami, co wzmacnia trwałość przekonania o własnej-socjologii-dojrzałości. Pojawiają się nawet spostrzeżenia, że na interdyscyplinarnej współpracy korzystają bardziej inne dyscypliny niż sami socjologowie.

Stereotypy - jak dobrze wiedzą o tym socjologowie - bywają zjawiskiem tak samo funkcjonalnym, jak i dysfunkcjonalnym. W kontekście tożsamości zawodowej środowiska socjologicznego są one niewątpliwie funkcjonalne. Tak jak opisywane przez nas jednostki i grupy wytyczamy symboliczne granice zbiorowości i rytualnie oraz deklaratywnie je wspieramy. Na ile jednak to poczucie „dojrzałości” (relatywnej oczywiście) socjologii nie powoduje do pewnego stopnia intelektualnej izolacji? Czy to, że inni korzystają więcej na współpracy niż socjologia nie oznacza niezdolności socjologów do przyswajania dorobku innych dyscyplin? Oczywiście nie można zarzucić socjologii, że zamyka się na wiedzę antropologiczną, demograficzną czy historyczną. Ta współpraca nie przełamuje jednak stereotypu, gdyż antropologia bywa często sprowadzana do subdyscypliny socjologii (czy też staje się swoistą w sensie metodologicznym wersją socjologii), zaś dwie pozostałe dyscypliny traktowane są pomocniczo, jako nauki opisowe. Jest więc w tym obrazie pewna tendencja do dominacji i myślenie postkolonialne, które tak efektywnie wskazujemy i piętnujemy w innych dziedzinach życia społecznego. Być może z racji przynależności do zbiorowości socjologów i podzielania pewnych schematów myślenia poniższe uwagi także będą skażone tą perspektywą. Wprowadzenie to jest jednak jednocześnie próbą pewnego przezwyciężania własnych przyzwyczajeń.

Czas w archeologii i socjologii. Pierwszym, najprostszym sposobem prowadzania dialogu między socjologią a archeologia jest zwrócenia uwagi na diachroniczny kontekst opisu życia społecznego. Dla archeologii postrzeganie życia społecznego w czasie jest naturalną perspektywą poznawczą. Socjologia zaś przez kontakt z archeologicznym myśleniem może uwrażliwić się na ów wymiar czasowy. Jest to aspekt z pewnych powodów niezwykle istotny, jednak bardzo dużo jest w tym skojarzeniu odniesień do relacji socjologii z historią. To samo bowiem pisano o wprowadzaniu kategorii struktur długiego trwania Fernanda Braudela (1999), która ma dziś w socjologii liczne grono zwolenników (zwłaszcza w socjologii narodu; por. Kłoskowska 1996; Altermatt 1998). Inną konsekwencją teoretyczną aplikowania perspektywy historycznej do socjologii (ale też przemian samej historii, która mocno zorientowała się na procesy społeczne i historię lokalną) jest socjologia historyczna (por. Kolasa 1996).

Fakt, że archeologia - tak jak historia - interesuje się przeszłością nie oznacza jednak, iż podejście tych dyscyplin do czasu jest identyczne. Kluczowe dla uchwycenia tej różnicy jest rozumienie kultury. Jak pisze Sylwester Czopek (2011: 332) w archeologii termin ten opisuje „zwartą chronologicznie i przestrzennie grupę źródeł i cech”. Definicja ta nie unika wieloznaczności pojęcia, tak powszechnie doświadczanej w antropologii i socjologii. Jednak ogólny (choć być może już trochę tradycyjny) uzus kategorii kultury - który socjolog zauważa w przeglądzie encyklopedycznym tej dyscypliny (Brezillon 1981) - pokazuje, że pod tą 
podstawową jednostką opisu i analizy kryją się zjawiska kojarzone przez historyków właśnie jako struktury długiego trwania. Okres, który w historii może być punktem dojścia w poszukiwaniach prawidłowości dziejowych, jest w archeologii punktem wyjścia, dzięki czemu właśnie archeologia możne mieć istotny głos w socjologicznej refleksji nad zmianą społeczna.

W tym kontekście archeologia i jej badania to istotny zasób wiedzy odnośnie do zmian w skali makrospołecznej, w tym globalnej. Socjologia w doświadczeniu takich zmian koncentruje się - przede wszystkim z powodu stosowanej metodologii i posiadanych danych - na tym, co w obecnej konfiguracji kulturowej dominuje lub zdobywa popularność. Inne zjawiska i cechy są słabo reprezentowane lub marginalizowane. Pewną wersją tych rozważań są pytania o cechy, które są nie tylko powszechne, lecz przede wszystkim istotne czy konstytutywne dla danego stanu rzeczy. Przykładem takiej refleksji jest koncepcja późnej nowoczesności Anthony'ego Giddensa (2001) czy rozważania nad dwudziestowieczną kulturą Zachodu Jamesa Clifforda (2000). Ich zestawienie z myśleniem archeologicznym wydaje się szczególnie inspirujące do formułowania nowych problemów badawczych oraz pozwala dostrzec podobieństwa między socjologią a archeologią. Obaj przywołani autorzy formułują tezę, że teraźniejszość Zachodu jest kontynuacją, a nawet pełną realizacją cech, które towarzyszą nam od czasów nowożytnych. To nowoczesność jest nową strukturą długiego trwania, którą Giddens (2001: 21) definiuje jako kategorię: „odnoszącą się do instytucji i wzorów zachowań, których początki sięgają końca europejskiego feudalizmu, chociaż znaczący wzrost ich realnego wpływu na losy świata zaznaczył się z całą intensywnością dopiero w wieku dwudziestym. Za odpowiednik «nowoczesności» można z grubsza przyjąć «świat uprzemysłowiony», pamiętając jednak, że industrializm nie jest jej jedynym wymiarem instytucjonalnym".

Jest to charakterystyka, która dobrze mieści się w myśleniu w kategoriach kultury archeologicznej i może być potraktowana jako ogólna próba jej wskazania, nawet $\mathrm{z}$ archeologicznymi źródłami, gdyż w następnym zdaniu A. Giddens pisze, że ,industrializm odnosi się do relacji społecznych wynikających z powszechnego zastosowania surowców energetycznych i maszyn w procesach produkcyjnych" [podkr. D.W.] (Giddens 2001: 21).

Takie porównanie nie daje jednak argumentów w przypadku założeń A. Giddensa, lecz jest tylko punktem wyjścia do głębszej refleksji nad procesami bardzo długiego trwania. Kultura archeologiczna jest spójną strukturą pewnych określonych cech. Współcześni archeolodzy nie są bynajmniej przekonani, że oznacza to logiczne istnienie w jej ramach jednej kultury etnograficznej. Patrząc na nowoczesność z perspektywy historycznej i socjologicznej, widać wyraźnie, że jest ona bardzo zróżnicowana w czasie i przestrzeni. Uwzględniając kontekst kultury archeologicznej, można dostrzec to, że tworzy ona zwarty zbiór cech - jest strukturą długiego trwania, lecz o perspektywach jej trwania jeszcze niewiele możemy powiedzieć.

Tutaj jednak archeologia proponuje nowe tropy i szersze (czasowo) powiązania. Wstępnie można przywołać J. Clifforda, który zgadzając się z ogólną genezą dzisiejszej kultury, mocniej akcentuje jako cechy konstytutywne miękkie cechy, wartości. Taką wartością która trwa w różnych kontekstach materialnych od XVI wieku jest indywidualizm (Clifford 2000: 106-107). Czy archeologia może sobie poradzić z takim zjawiskiem? Przekrojowe analizy różnych kultur archeologicznych od VI do II tysiąclecia, cechujących się silną hierarchią społeczną i wysoką pozycją polityczną nielicznej grupy mężczyzn (Kadrow 2010; Kadrow 2011a), pokazują, że analiza w kontekście wartości lepiej tłumaczy istnienie podobieństw 
między odległymi w czasie jednostkami kulturowymi, niż czynią to koncepcje migracyjne. Archeologiczny świat rzeczy może naprowadzać także na rozpoznanie wartości. Tym samym otwiera przed rozpoznawanymi dziś wartościami nową perspektywę czasową. Prowokuje pytanie, na ile to, co dziś powszechne, zasadza się na strukturach „logiki rozwoju” (Kadrow 2011a: 26), stanowi tylko wyraz konkretnej realizacji takiej struktury.

Archeologia i socjologia życia codziennego: konkretność zdarzeń społecznych. Archeologia, tak samo jak socjologia, jest nauką wieloparadygmatyczną (por. Dzbyński 2008: 19-20). Jak wskazał powyżej S. Kadrow, różne paradygmaty archeologiczne mają swoje odpowiedniki w innych dyscyplinach humanistycznych, w tym w socjologii. Aleksander Dzbyński, określając się jako zwolennik archeologii kognitywno-procesualnej, wskazuje na takie jej cechy, jak poszukiwanie kognitywnych i symbolicznych aspektów działania czy kontekstualny sposób postrzegania danych (źródeł) (por. Dzbyński 2008: 19-20). Autor ów odnosi się do koncepcji racjonalności M. Webera i ,świata życia”, który w socjologii kojarzy się nie tylko z twórczością J. Habermasa, ale też A. Schutza (2008) czy P. Bergera i Th. Luckmanna (1966). Powoduje to, że podstawowe pytania badawcze u A. Dzbyńskiego - choć odnoszą się do cech wiórów, paciorków i brązowych sierpów - zakorzenione są w humanistycznym myśleniu o świecie społecznym. Są to bowiem pytania o to, jak owe rzeczy są rozumiane i komunikowane. Cechy makrolitów i ich lokacja w kontekstach przestrzennych pozwalają na logiczne odczytanie intersubiektywnego Lebenswelt ich wytwórców i użytkowników. Odwołanie się do socjologicznej perspektywy rozumiejącej i teorii J. Habermasa w takich pracach ma konsekwencje także dla samej socjologii.

Wydaje się, że w tej perspektywie teoretyczno-metodologicznej szczególnie, a szerzej we wszystkich badaniach, które orientują się na dokładne rozpoznanie kontekstu mikro- i mezospołecznego (np. archeologia osadnictwa, badania technologii krzemiennych itp.), archeologia rozwija takie sposoby ujmowania rzeczywistości ludzkiej, które nie tylko uzupełniają przyzwyczajenia socjologiczne - polegające na tym, że świat przeżywany może być nam dany w bezpośredniej komunikacji z jego „użytkownikiem” - ale istotnie mogą rozwinąć horyzont poznawczy socjologii. Sprawa dotyczy rzeczy (por. Zalewska 2014; Wolski 2014), a dokładnie bardzo precyzyjnej metodologii archeologicznej odnoszącej się do badania rzeczy (np. Dzbyński 2008; Wolski 2014), ale też przestrzeni (Połtowicz-Bobak 2011), czyli de facto rzeczywistości materialnej, która jest istotnym kontekstem (środowiskiem) procesów społecznych (Sztompka 2005: 218). To bowiem doświadczenie metodologiczne archeologów w połączeniu z perspektywą humanistyczną (rozumiejąca) znacząco prześciga socjologiczne poszukiwania w wyznaczanym właśnie obszarze socjologii zdarzeniowej czy socjologii codzienności (por. Sztompka 2008; Urry 2008). Wydaje się bowiem, że właśnie skupienie się socjologów na świecie społecznym traktowanym jako zdarzenia (a wcześniej „ciagły strumień zachowań"; Giddens 2003: 41) pozwala nam na dostrzeżenie nie tylko przebiegu i efektów zmiany społecznej, ale i mechanizmu tej zmiany. Modelami takich mechanizmów jest teoria strukturacji A. Giddensa czy też teoria stawania się społeczeństwa P. Sztompki. Przejście od modelu do konkretu badań pozostawia w socjologii wiele do życzenia.

Wydaje się, że brakuje w socjologii mocnego przekonania, że analiza powiązania świata rzeczy ze światem społecznym (,światem życia”) to coś więcej niż weryfikacja błędnych danych bazujących na wypowiedziach i interpretacjach aktorów społecznych. Jeżeli spojrzymy 
na ów świat rzeczy jako na istotną część środowiska fizycznego, w którym wyraża się (a nie tylko realizuje się) proces społeczny, to powiązania między nimi mogą być źródłem odkrycia nowych fenomenów społecznych. Oczywiście trzeba też założyć wielokierunkowość powiązań pomiędzy światem rzeczy a procesem społecznym, co pozwala na wnioskowanie ze stanu rzeczy o procesie. Przywołane wyżej prace archeologicznie nie tyle wyrażają takie założenia, co je empirycznie i logicznie uzasadniają; empirycznie, gdyż opierają się na silnym wsparciu źródeł. Logicznie zaś dlatego, że opierając się na czytelnych procedurach analizy, wskazują na powiązanie tych rzeczy z intersubiektywnym ,światem życia”. Archeologia wypełnia metodologiczną i badawczą lukę pomiędzy nowymi pomysłami socjologów a ich dawnymi przyzwyczajeniami metodologicznymi.

\section{WNIOSKI}

Archeologia i socjologia to dyscypliny wieloparadygmatyczne, zaś rozwój poszczególnych stanowisk teoretycznych w ich ramach ma charakter paralelny. Powoduje to, że wyniki współczesnych badań archeologów i socjologów mogą być poprawnie komunikowane. Umożliwia to prowadzenie wspólnej dyskusji metodologicznej i teoretycznej na warunkach równoprawnych aktorów.

Owe dwie dyscypliny charakteryzuje różne doświadczenie kontaktów interdyscyplinarnych. W archeologii są one bardzo szerokie i postrzegane pozytywnie. W doświadczeniu socjologicznym są one rzadsze i mniej efektywnie wykorzystywane.

Szczególnym obszarem obopólnie korzystnej wymiany intelektualnej są badania zorientowane na rozpoznanie ,świata rzeczy” oraz trwania i zmiany w życiu codziennym. W tym obszarze wiedza i metodologia archeologiczna podpowiadają, jak wiele można odczytać kontekstów społecznych ze ,świata rzeczy”, zaś socjologia mogłaby powiązać tu i teraz wyniki prowadzonych na tej płaszczyźnie badań.

\section{BIBLIOGRAFIA}

Altermatt, Urs. 1998. Sarajewo przestrzega. Etnonacjonalizm w Europie, Kraków: Znak. Barański, Janusz. 2007. Świat rzeczy. Zarys antropologiczny, Kraków: Anthropos.

Barney, Darin. 2008. Spoleczeństwo sieci, Warszawa: Wydawnictwo Sic!

Berger, Peter i Thomas Luckmann. 1966. The Social Construction of Reality. A Treatise in the Sociology of Knowledge, New York: Anchor Books.

Bourdieu, Pierre. 2007. Szkic teorii praktyki poprzedzony trzema studiami na temat etnologii Kabylów, Kęty: Wydawnictwo Marek Derewiecki.

Braudel, Fernand. 1999. Historia i trwanie, Warszawa: Czytelnik.

Brezillon, Michael. 1981. Encyklopedia kultur pradziejowych, Warszawa: Wydawnictwa Filmowe i Artystyczne.

Castells, Manuel. 2013. Społeczeństwo sieci, Warszawa: Wydawnictwo Naukowe PWN.

Clifford, James. 2000. Kłopoty z kultura, Poznań: Zysk i S-ka. 
O dyskursie archeologiczno-socjologicznym

Czopek, Sylwester. 2011. Cultural Change from the Perspective of Cultural-Historical Archeology, „Analecta Archaeologica Ressoviensia” 6: 317-341.

Dant, Tim. 2007. Kultura materialna w rzeczywistości społecznej, Kraków: Wydawnictwo Uniwersytetu Jagiellońskiego.

DeMarrais, Elisabeth, Chris Gosden i Colin Renfrew (red.). 2004. Rethinking materiality. The engagement of mind with the material world, Cambridge: McDonalds Institute for Archaeological Research.

Domańska, Ewa i Bjornar Olsen. 2008. Wszyscy jesteśmy konstruktywistami, w: Jacek Kowalewski, Wojciech Piasek i Marta Śliwa (red.), Rzeczy i ludzie. Humanistyka wobec materialności, Olsztyn: Instytut Filozofii Uniwersytetu Warmińsko-Mazurskiego, s. 83-100.

Dzbyński, Aleksander. 2008. Rytuat i porozumienie. Racjonalne podstawy komunikacji $i$ wymiany w pradziejach Europy Środkowej, „Collectio Archaeologica Ressoviensis” 8, s. $290-310$.

Fukuyama, Francis. 2012. Historia ładu politycznego. Od czasów przedludzkich do rewolucji francuskiej, Poznań: Rebis.

Furholt, Martin. 2009. Polithetic classification and measures of similarity in material culture. A quantitative approach to Baden culture material, „Analecta Archaeologica Ressoviensia" 4: 225-263.

Giddens, Anthony. 2001. Tożsamość i późna nowoczesność, Warszawa: PWN.

Giddens, Anthony. 2003. Stanowienie społeczeństwa. Zarys teorii strukturacji, Poznań:Zysk i S-ka. Gumilow, Lew. 1997. Dzieje etnosów wielkiego stepu, Kraków: Oficyna Literacka.

Habermas, Jürgen. 1983. Próba rekonstrukcji materializmu historycznego, w: Jürgen Habermas, Teoria i praktyka, Warszawa: Państwowy Instytut Wydawniczy, s. 475-532.

Habermas, Jürgen. 1999. Teoria działania komunikacyjnego. Tom 1. Racjonalność działania a racjonalność społeczna, Warszawa: Wydawnictwo Naukowe PWN.

Habermas, Jürgen. 2002. Teoria działania komunikacyjnego. Tom 2. Przyczynek do krytyki rozumu funkcjonalnego, Warszawa: Wydawnictwo Naukowe PWN.

Hodder, Ian. 1995. Czytanie przeszłości, Poznań: Obserwator.

Johansen, Kasper L., Steffen T. Laursen i Mads K. Holst. 2004. Spatial patterns of social organization in the Early Bronze Age of South Scandinavia, ,Journal of Anthropological Archaeology" 23: 33-55.

Kadrow, Sławomir. 2009. The Early Copper Age: Socio-cultural Process in Modern Sociological Interpretation, „Analecta Archaeologica Ressoviensia” 4, s. 265-302.

Kadrow, Sławomir. 2010. Examples of Migration in the Early Phases of the Metal Ages from a Contemporary Sociological Perspective, w: Karol Dzięgielewski, Marcin Przybyła i Anna Gawlik (red.), Migration in Bronze and Early Iron Age Europe, Kraków: Księgarnia Akademicka, s. 47-61.

Kadrow, Sławomir. 2011a. Power and Authority in Prehistory and the Problem of Interdisciplinary Archaeological Studies, „Analecta Archaeologica Ressoviensia” 6: 11-54.

Kadrow, Sławomir. 2011b. Kupferzeitliche Sozialstrukturen, w: Hansen Svend i Johannes Müller (red.), Sozialarchäologische Perspektiven: Gesellschaftlicher Wandel 5000-1500 v.Chr. zwischen Atlantik und Kaukasus. Internationale Tagung 15.-18. Oktober 2007 Kiel (=Archäologie in Eurasien 24), Mainz, s. 107-121. 
Kolasa, Agnieszka. 1996. Socjologia historyczna - problemy przedsięwzięcia interdyscyplinarnego, „Historyka. Studia Metodologiczne” 26: 3-20.

Kłoskowska, Antonina. 1996. Kultury narodowe u korzeni, Warszawa: PWN.

Krajewski, Marek. 2008. Ludzie i przedmioty - relacje i motywy przewodnie, w: Jacek Kowalewski, Wojciech Piasek i Marta Śliwa (red.), Rzeczy i ludzie. Humanistyka wobec materialności, Olsztyn: Instytut Filozofii Uniwersytetu Warmińsko-Mazurskiego, s. 131-152.

Maffesoli, Michel. 2008. Czas plemion. Schyłek indywidualizmu w społeczeństwach ponowoczesnych, Warszawa: Wydawnictwo Naukowe PWN.

Morgan, Luis. 1877. Ancient Society or Researches in the Lines of Human Progress from Savagery through Barbarism to Civilisation, London: McMillan.

Pare, Christopher. 2008. Archaeological Periods and their Purpose, w: Lehoërff Anne (red.), Construire le temps. Histoire et méthodes des chronologies et calendriers des derniers millénaires avant notre ère en Europe occidentale. Actes du XXXe colloque international de Halma-Ipel, UMR 8164 (CNRS, Lille 3, MCC) 7.-9. décembre 2006 (= Collection Bibracte 16), Glux-en-Glenne, s. 69-84.

Podgorny, Irina. 2000. The "Non-Metallic Savages": the use of analogy in Victorian geological archaeology and French Palaeoethnology and its reception in Argentina in the decade of 1870, w: Alexander Gramsch (red.), Vergleichen als archäologische Methode. Analogien in den Archäologien. Mit Beiträgen einer Tagung der Arbeitsgemeinschaft Theorie (T-AG) und einer Kommentierten Bibliographie (= British Archaeological Reports. International Series 825), Oxford: Archaeopress, s. 19-38.

Połtowicz-Bobak, Marta. 2011. Space in Archeological Research-Methods of reading and Interpretation, "Analecta Archaeologica Ressoviensia" 6: 237-270.

Rossignol Sebastien i Donat Wehner. 2010. Methodologische Überlegungen zur interdisziplinären Erforschung von herrschaft am Beispiel Ostmitteleuropas vom 9. zum 13. Jahrhundert, w: Aleksander Paroń, Sebastien Rossignol i Grisha Vercamer (red.), Potestas at communitas. Interdisziplinäre Beiträge zu Wessen und Darstellung von Herrschaftsverhältnissen im Mittelalter östlich der Elbe, Warszawa: Instytut Archeologii i Etnologii PAN, s. 23-52.

Schnapp, Alain i Kristian Kristiansen. 1999. Discovering the Past, w: Barker Graeme (red.), Companion Encyclopedia of Archaeology, t. I, London: Routledge, s. 3-47.

Schutz, Alfred. 2008. O wielości światów. Szkice z socjologiifenomenologicznej, Kraków: Nomos. Sojak, Radosław. 2004. Paradoks antropologiczny. Socjologia wiedzy jako ogólna teoria społeczeństwa, Monografie Fundacji na rzecz Nauki Polskiej, Wrocław: Wydawnictwo Uniwersytetu Wrocławskiego.

Szacki, Jerzy. 2007. Historia myśli socjologicznej, wydanie nowe, Warszawa: Wydawnictwo Naukowe PWN.

Sztompka, Piotr. 1991. Society in Action: The Theory of Social Becoming, Oxford: Polity Press. Sztompka, Piotr. 2005. Socjologia zmian społecznych, Kraków: Wydawnictwo Znak.

Sztompka, Piotr. 2008. Życie codzienne - temat najnowszej socjologii, w: Sztompka Piotr i Magdalena Bogunia-Borowska (red.), Socjologia codzienności, Kraków: Znak, s. 15-52. Tabaczyński, Stanisław. 2012. Socjologia pradziejów. Zarys problematyki, w: Stanisław Tabaczyński, Arkadiusz Marciniak, Dorota Cyngot i Anna Zalewska (red.), Przeszłość społeczna. Próba konceptualizacji, Poznań: Wydawnictwo Poznańskie, s. 732-769. 
Turner, Jonathan H. 2004. Struktura teorii socjologicznej, wydanie nowe, Warszawa: Wydawnictwo Naukowe PWN.

Urbańczyk, Przemysław. 2006. Where does the “return to things” lead us?, „Archaeologia Polona" 44: 187-194.

Urry, John. 2008. Sieci społeczne, podróże i rozmowy, w: Piotr Sztompka i Magdalena Bogunia-Borowska (red.), Socjologia codzienności, Kraków: Znak, s. 259-285.

Wolski, Damian. 2014. Technologie krzemieniarskie w świetle wybranych koncepcji psychologii społecznej - na przykładzie wczesnobrqzowych narzędzi bifacjalnych z Małopolski, „Studia Humanistyczne AGH” 13/2: 147-154.

Van Reybrouck, David. 2000. Beyond ethnoarchaeology? A critical history on the role of ethnographic analogy in contextual and post-processual archaeology, w: Gramsch Alexander (red.), Vergleichen als archäologische Methode. Analogien in den Archäologien. Mit Beiträgen einer Tagung der Arbeitsgemeinschaft Theorie (T-AG) und einer Kommentierten Bibliographie (= British Archaeological Reports. International Series 825), Oxford: Archaeopress, s. 39-51.

Zalewska, Anna. 2014. Prospołeczna, partycypacyjna i ,wspólnotowa” archeologia bliskiej przeszłości jako sposób na nadawanie sensu trwaniu (ludzi i rzeczy)oraz jako antidotum na niedostatki wiedzy i trywializację przeszłości, „Studia Humanistyczne AGH” 13/2: 19-39.

\section{ON ARCHEOLOGICAL-SOCIOLOGICAL DISCOURSE}

Abstract: The article tries to show fundamental theoretic and cognitive issues, that seem common for archeology and sociology. Their existence allows not only to implement a common scientific discourse, but also it may inspire the growth of each discipline. As far as we are concerned, common reflection upon meaning of "things" for the existence of social world, and recognition of mechanisms that create everyday life is exceptionally inspiring. Moreover, both disciplines have similar experiences with multiplicity of theoretical-methodological paradigms and contend with the issue of change and continuity of culture (using different time perspectives).

Key words: archeological-sociological discourse, "return to things" in humanities, theories of society and archeological research, archeology and sociology of everyday life 